Nalar: Jurnal Peradaban dan Pemikiran Islam

Vol. 2, No. 2, Desember 2018

\title{
Penafsiran Kontekstualis perihal Kepemimpinan Non-Muslim dalam Perspektif Alquran dan Hadis
}

\author{
M. Agus Muhtadi Bilhaq \\ Pascasarjana UIN Sunan Kalijaga Yogyakarta \\ bil_haq@hotmail.com
}

\begin{tabular}{|c|c|}
\hline \multicolumn{2}{|r|}{ Abstrak } \\
\hline $\begin{array}{l}\text { Article History } \\
\text { Received: 11-9-2018 } \\
\text { Revised : 21-11-2018 } \\
\text { Accepted: 28-11-2018 } \\
\text { Kata Kunci : } \\
\text { Penafsiran Kontekstualis, } \\
\text { Pemimpin, } \\
\text { Non-Muslim, } \\
\text { Al-Maidab 51, } \\
\text { Auliā, } \\
\text { Hadis. }\end{array}$ & 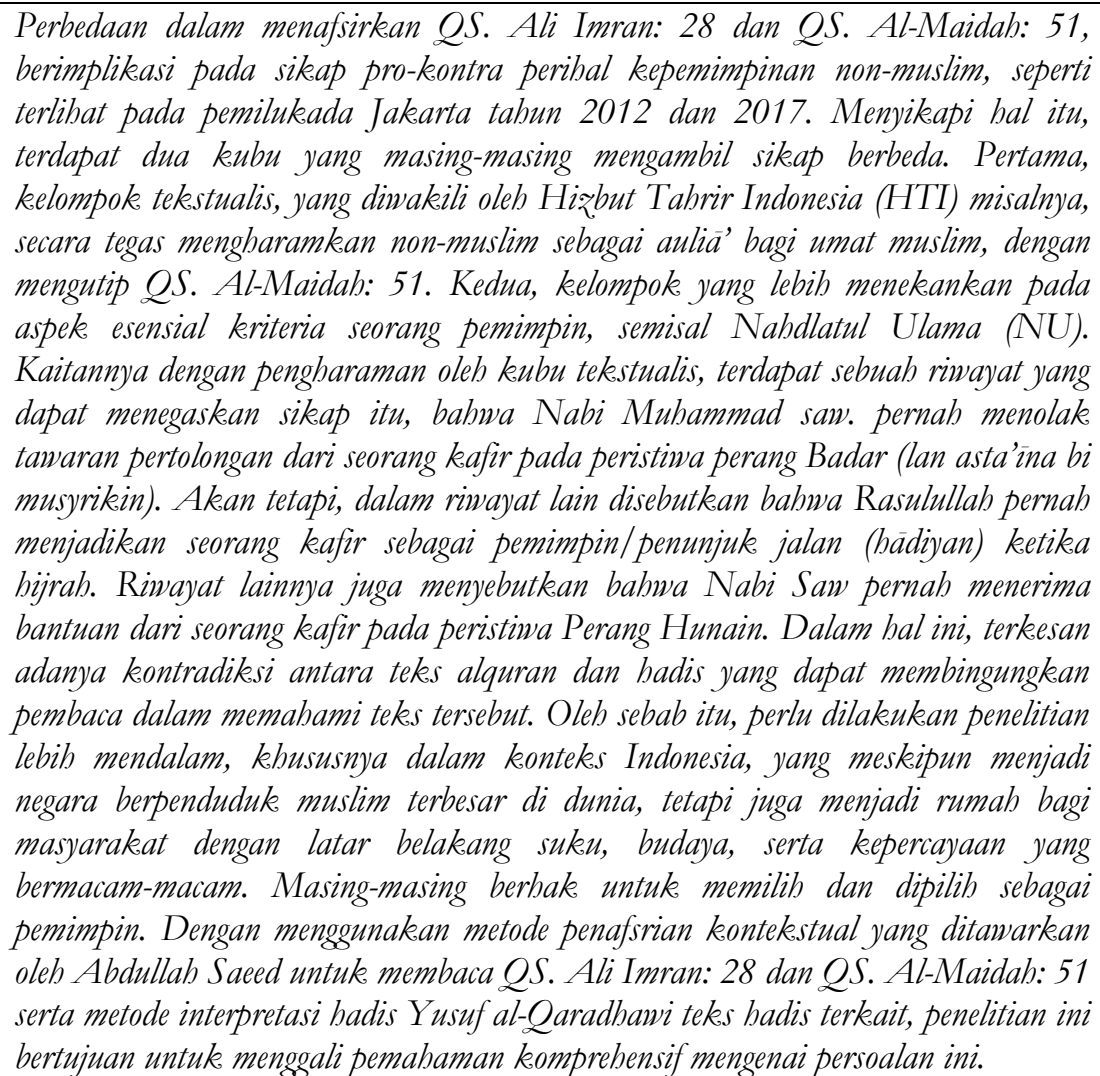 \\
\hline
\end{tabular}

\section{Pendahuluan}

Perdebatan tentang boleh-tidaknya seorang non-muslim menjadi pemimpin bagi muslim, sesungguhnya merupakan fenomena klasik yang senantiasa menarik perhatian ulama maupun peminat studi politik Islam. Beragam karya maupun diskusi telah banyak membahas tema ini. Persoalan ini terjadi karena adanya perbedaan dalam memahami teks suci alquran maupun hadis. Bagi kelompok tekstualis misalnya, adalah haram hukumnya bagi umat muslim dipimpin oleh seorang non-muslim (kafir), sebab sejalan dengan firman Allah Swt., sebut saja di antaranya QS. Ali Imran (3): 28 dan QS. Al-Maidah (5): 51. Oleh karena itu, kelompok itu memiliki keyakinan bahwa mengangkat orang kafir sebagai pemimpin atau penolong adalah haram hukumnya menurut Syariat Islam.

Sementara itu, di sisi lain ada juga kelompok atau pendapat yang lebih menekankan pada aspek esensial seorang pemimpin, dan bukan pada harus Islam atau tidaknya seorang pemimpin. Aspek esensial itu mencakup kecakapan dalam memimpin, amanah, bertanggung jawab, serta mampu mewujudkan kesejahteraan-keadilan sosial di masyarakat. Dengan demikian, masyarakat dapat memperoleh kebaikan sebagaimana dicita-citakan oleh Islam. Salah satu tokoh muslim yang memiliki paham seperti ini adalah Ibnu Taimiyah. Abu 
Nalar: Jurnal Peradaban dan Pemikiran Islam

Vol. 2, No. 2, Desember 2018

Tholib Khalik (2014:76) mengutip pendapat Ibnu Taimiyah, bahwa keadilan adalah penopang pemerintahan sekaligus menjadi syarat datangnya pertolongan Tuhan.

Apabila dikaitkan dengan konteks Indonesia, diskursus ini sangatlah menarik, sebab meski menjadi negara dengan penduduk muslim terbesar di dunia, Indonesia juga menjadi rumah bagi masyarakat dengan latar belakang suku, budaya, serta kepercayaan yang bermacam-macam. Oleh sebab itu, atas dasar ideologi Pancasila dan asas demokrasi yang dianut, masing-masing warga negara Indonesia berhak untuk mencalonkan diri dan dipilih menjadi pemimpin, tanpa membedakan-bedakan suku, etnis, warna kulit, maupun agama.

Persoalan yang muncul kemudian adalah ketika hal ini -hak yang sama bagi masingmasing warga negara Indonesia untuk menjadi pemimpin -dihadapkan secara vis a vis dengan agama (Islam). Pelbagai respon bermunculan dalam menyikapi persoalan itu, baik pro maupun kontra. Tidak jarang bentuk reaktif berupa aksi atau demonstrasi dilakukan sebagai bentuk penolakan terhadap pemimpin non-muslim. Sebagai contoh, perdebatan cukup alot mengemuka ketika pasangan Joko Widodo bersama wakilnya yang seorang nonmuslim, Basuki Tjahaja Purnama, mencalonkan dan terpilih sebagai gubernur DKI Jakarta pada 2012, serta yang terbaru ketika Basuki Tjahaja Purnama maju mencalonkan diri sebagai gubernur pada pilkada DKI 2017.

Pada pemilukada DKI tahun 2012, isu dilarangnya umat muslim memilih pemimpin non-muslim mencuat setelah Rhoma Irama berceramah di salah satu masjid di Jakarta Barat. Dalam ceramahnya, Rhoma Irama menyampaikan bahwa umat muslim akan mendapat sanksi atau azab dari Allah Swt. apabila memilih pemimpin non-muslim -dalam konteks pemilukada waktu itu adalah Basuki Tjahaja Purnama (Ahok) yang maju sebagai calon wakil gubernur dari Joko Widodo. Bahkan dalam ceramahnya, Rhoma Irama terindikasi memuat konten berbau SARA (suku, agama, rasa, dan antargolongan), dan berpotensi membuatnya terjerat kasus hukum (kompas.com, 2012). Sementara itu, aksi demonstrasi gabungan antarorganisasi masyarakat (ormas) Islam sebagai bentuk penolakan terhadap pemimpin kafir juga pada 04 September 2016 lalu. Dalam aksi itu, mereka secara tegas menolak pemimpin kafir (Ahok) dalam pemilukada DKI 2017, sebab alquran secara tegas mengharamkannya (republika.co.id, 2016).

Meskipun demikian, seperti telah disinggung sebelumnya, tidak hanya respon kontra atau penolakan terhadap calon pemimpin non-muslim yang muncul. Ada juga pendapat yang lebih menekankan pada aspek esensial seorang pemimpin, seperti pendapat KH. Irwan Masduqi, misalnya. Pengasuh Pesantren Assalafiyyah 2 Terpadu Yogyakarta itu berpendapat bahwa prinsip memilih pemimpin dalam Islam adalah memilih calon yang memiliki kemampuan dan memiliki kejujuran, sehingga mampu mengemban amanah rakyat secara adil. KH. Irwan Masduqi mengutip riwayat di mana Rasulullah saw. pernah memercayakan para sahabatnya untuk hijrah ke Ethiopia mencari suaka dari pemerintahan Raja Najasyi yang Kristen tetapi adil. Atas dasar riwayat itu, menurutnya, umat muslim tidak dilarang memilih pemimpin non-muslim (tribunnews.com, 2017).

Selain itu, intelektual muslim Indonesia lainnya, seperti KH. Ahmad Ishomuddin, saat itu menjabat sebagai Rais Syuriah PBNU, dan Dr. Sahiron Syamsuddin, dosen Tafsir Alquran Universitas Islam Sunan Kalijaga Yogyakarta, memaknai kata auliā pada QS. 5: 51, lebih pada teman setia, dan bukan pemimpin -dengan memperhatikan aspek bahasa, sejarah, dan pesan utama ayat itu. Sahiron juga merujuk fatwa mufti Mesir - perihal boleh tidaknya memilih pemimpin non-muslim -yang memperbolehkan masyarakat Mesir untuk memilih pemimpin non-muslim, meskipun penduduk mayoritas negara itu beragama Islam (tempo.co, 2017).

Demikian juga dengan Nahdlatul Ulama (NU), salah satu ormas Islam terbesar di Indonesia, pernah menerbitkan fatwa pada 1999 perihal pemimpin non-muslim. Dalam 
Nalar: Jurnal Peradaban dan Pemikiran Islam

Vol. 2, No. 2, Desember 2018

fatwa itu dijelaskan bahwa boleh memilih pemimpin non-muslim dengan catatan, pertama memang tidak ada orang Islam yang mampu memimpin. Kedua, ada calon beragama Islam, tetapi karena dikhawatirkan berkhianat, boleh memilih alternatifnya yang non-muslim. Ketiga, diperbolehkan memilih pemimpin non-muslim selama tokoh itu dianggap tidak jadi ancaman bagi umat muslim (kompas.com, 2016).

Menyikapi hal ini, apabila merujuk pada QS. 3: 28, QS. 4: 144, atau QS. 5: 51 misalnya, secara eksplisit teks ayat-ayat tersebut tegas melarang umat muslim untuk menjadikan non-muslim sebaga auliä' (bentuk jamak dari kata waliyyun). Namun demikian, perlu digarisbawahi bahwa makna dari kata waliyyun sendiri bermacam-macam, di antaranya bermakna pemimpin (waliyyu al-amri), penolong (nasirun), teman (șodiqun), dan bisa juga bermakna pemilik (mälikun, șāhibun) (Baalbaki 1995: 1248). Untuk itu, dalam menafsirkan ayat tersebut perlu memperhatikan aspek bahasa, konteks sejarah, sabab nuzul, dan pesan utama (nilai universal) ayat-ayat itu. Persoalannya, cara pandang atau pendekatan yang jamak digunakan untuk memahami ayat-ayat itu adalah tekstualis. Sehingga, kata auliä seakan-akan hanya mengacu pada makna pemimpin semata, yang pada akhirnya bermuara pada larangan bagi umat muslim memilih auliä' dari kalangan non-muslim. Dalam konteks Indonesia, hal ini menjadi isu yang sensitif dan rentan melahirkan konflik, mengingat Indonesia didiami oleh masyarakat dengan latar belakang budaya, suku, dan agama yang beragam.

Sementara itu, berbanding terbalik dengan pendangan kelompok muslim fundamentalis yang "mengharamkan" menjadikan non-muslim sebagai pemimpin -dan bahkan ormas Hizbut Tahrir Indonesia (HTI) dengan mengutip Ibn Katsir lebih jauh pun melarang meski sekadar untuk bersahabat, berteman, serta saling memberi dan meminta nasihat -Nabi Muhammad saw. sendiri, dalam sebuah riwayat, dikatakan pernah menjadikan seorang kafir (Abdullah bin Uraiqit) sebagai pemimpin atau penunjuk jalan (bädiyan, hädin berasal dari kata hadă), dalam perjalanan hijrah dari Makkah menuju Yasrib. Dalam riwayat lain, pun disebutkan bahwa pada peristiwa Perang Hunain, Rasulullah saw. menerima bantuan dari Shafwan bin Umayah, yang pada saat itu masih dalam keadaan kafir.

Merujuk pada teks alquran dan hadist sebagaimana telah disebutkan, terkesan "seolah-olah" ada kontradiksi antara teks alquran dan hadist. Sebagaimana telah disinggung sebelumnya, QS. 3 : 28 dan QS. 5 : 51 secara eksplisit (tekstual) melarang muslim menjadikan kafir atau non-muslim sebagai auliä, sementara pada kenyataannya, Rasulullah Saw sendiri, pernah menjadikan seorang kafir sebagai penunjuk jalannya serta menerima bantuan dari seorang kafir pula dalam peristiwa perang Hunain. Padahal, umat muslim meyakini bahwa apa yang dilakukan oleh Nabi Muhammad saw., merupakan cerminan dari nilai-nilai suci alquran. Untuk itu, hemat penulis, perlu dilakukan pengkajian yang lebih komprehensif perihal kepemimpinan non-muslim dengan merujuk pada teks hadis dan alquran di atas.

\section{Metode Interpretasi Hadis Yusuf al-Qaradlawi dan Pendekatan Kontekstualis Abdullah Saeed}

Tulisan ini lebih lanjutkan membahas hadis-hadis serta ayat-ayat alquran terkait pembahasan kepemimpinan non-muslim (sebagai penolong). Seperti telah disinggung sebelumnya, antara teks alquran dan hadis yang penulis dapati, terkesan "seolah-olah" memiliki kontradiksi. Pada QS. 3: 28 dan QS. 5: 51 secara eksplisit (tekstual) melarang muslim menjadikan kafir atau non-muslim sebagai auliä, sementara pada kenyataannya, Rasulullah saw. sendiri, pernah menjadikan seorang kafir sebagai penunjuk jalannya, serta 
Nalar: Jurnal Peradaban dan Pemikiran Islam

Vol. 2, No. 2, Desember 2018

menerima bantuan dari seorang kafir pula dalam peristiwa Perang Hunain. Untuk itu, penulis kemudian menggunakan dua macam pendekatan atau metode interpretasi teks.

Penulis menggunakan metode interpretasi hadis Yusuf al-Qaradlawi untuk mengkaji teks-teks hadis. Dalam hal ini, metode interpretasi hadist Yusuf al-Qaradlawi yang penulis gunakan adalah metode pengkompromian atau harmonisasi (al-jam'u) dan tarjih (pengunggulan) antara hadis yang tampaknya berbeda (mukbtalif). Dalam kitabnya, Kaifa nata'ämalu ma'a as-sunnah an-nabawiyyah, Yusuf al-Qaradlawi (1992: 113) menyebutkan bahwa pada dasarnya tidak ada pertentangan antarteks/nash syar'iyah, sebab tidak mungkin sesuatu yang benar bertentangan dengan kebenaran. Sekalipun ditemukan pertentangan (antara dua hal yang benar), maka sesungguhnya pertentangan itu hanya dalam tataran dhabir (hanya tampak bertentangan), tetapi tidak secara esensi. Apabila memungkinkan antara dua teks yang saling bertentangan itu dikompromikan (al-jam' $u$ ), maka pengkompromian harus didahulukan dari pen-tarjih

Dalam pengaplikasian metode pengkompromian atau harmonisasi ini, penulis menggunakan pemahaman kontekstualis, yaitu memahami hadis-hadis Rasulullah saw. dengan memperhatikan dan mengkaji keterkaitannya dengan peristiwa (konteks yang melatarbelakanginya), dengan kata lain, memperhatikan dan mengkaji konteksnya (Bay 2011:190). Hal ini perlu dilakukan, sebab selain riwayat yang mengisahkan tentang pernahnya Nabi Muhammad menerima bantuan dari seorang kafir, penulis juga menemukan riwayat lain yang bercerita tentang penolakan Nabi saw. terhadap tawaran atau bantuan seorang kafir dalam peperangan. Sementara itu, secara kualitas masing-masing hadis itu memiliki posisi yang sama kuat (shahib).

Selanjutnya, untuk mengkaji serta menggali makna ayat-ayat alquran, dalam hal ini adalah QS. 3: 28 dan QS. 5: 51, penulis menggunakan pendekatan kontekstualis Abdullah Saeed. Pondasi awal model pendekatan kontekstual ini sebenarnya telah diletakkan oleh Fazlur Rahman dengan teori double movement-nya. Fazlur Rahman berpandangan bahwa dalam membaca alquran seseorang harus kembali ke masa lalu, memahami konteks di mana alquran diturunkan, kemudian membawa nilai-nilai masa lalu itu pada saat ini (Rachmawan, 2013: 154). Namun, konsep yang ditawarkan Fazlur Rahman ini masih menyisakan kekurangan. Selain itu, Rahman sendiri tidak begitu menjelaskan mengenai langkah-langkah kontekstualisasi secara terperinci. Rahman juga tidak mengaitkan masalah kontekstualisasi dengan perkembangan ilmu pengetahuan. Kekurangan itu kemudian direspon dan disempurnakan oleh Abdullah Saeed.

Menurut Abdullah Saeed (2015:6-7), di kalangan umat muslim, terdapat tiga pendekatan besar yang mungkin diidentifikasi dalam kaitannya dengan interpretasi ayat-ayat eticho-legal pada periode modern. Pertama, kelompok tekstualis; memberikan penekanan dalam aspek bahasa. Kelompok ini mengadopsi pendekatan literalistik terhadap teks. Bagi kelompok ini, konteks sosio-historis ayat tidak begitu penting. Kedua, kelompok semitekstualis. Kelompok ini pada dasarnya mengikuti tekstualis dalam hal penekanan pada linguistik, tetapi kelompok ini sudah menggunakan idiom-idiom modern. Ketiga, kelompok kontekstualis, yakni kelompok yang menekankan pada konteks sosio-historis, khususnya terhadap ayat-ayat eticho-legal.

Untuk melakukan pembacaan terhadap alquran, ada beberapa prinsip yang harus disadari terlebih dahulu. Prinsip-prinsip tersebut di antaranya adalah pertama, penafsir harus menyadari bahwa alquran lahir dalam setting socio-historical context tertentu. Hal ini penting untuk menghantarkan pembaca pada sebuah kesadaran sejarah, bahwa alquran tidak lahir dalam ruang kosong. Selain itu, dengan mengetahui konteks di mana alquran lahir akan memudahkan seorang penafsir berinteraksi dengan masa dan kondisi di mana alquran diwahyukan. Kedua kontekstualisasi alquran berakar dari tradisi Islam (Rachmawan, 
Nalar: Jurnal Peradaban dan Pemikiran Islam

Vol. 2, No. 2, Desember 2018

2013:154-155). Dalam Interpreting the Qur'an misalnya, Abdullah Saeed (2015:170) mencontohkan penafsiran yang dilakukan oleh Umar ra. yang terkesan "menyalahi" perintah-perintah alquran dalam beberapa kasus, semisal tentang zakat dan perceraian. Hal ihwal ini menjadi dasar bahwa kontekstualisasi dalam penafsiran telah dilakukan sejak masa Islam generasi awal.

Abdullah Saeed (2015:257) menyebutkan, bahwa hal terpenting dalam melakukan penafsiran kontekstualis adalah pemahaman atas hirarki nilai dalam alquran, yakni nilai yang bersifat kewajiban (Obligatory Values), nilai fundamental (Fundamental Values), nilai perlindungan (Protectional Values), nilai implementasi (Implementational V $V$ alues), dan nilai istruksional (Intructional Values). Pertama, nilai-nilai yang bersifat kewajiban (Obligatory Values). Nilai ini adalah mencakup periode Makkah maupun Madinah dan tidak bergantung kepada budaya. Nilai-nilai yang bersifat wajib ini dapat juga diartikan sebagai doktrin agama yang hingga kapan pun tidak akan berubah. Yang termasuk pada hirarki nilai yang pertama adalah seperti iman, ibadah, dan tentang halal-haram. Kedua, nilai-nilai fundamental (Fundamental Values). Nilai-nilai fundamental ini oleh Saeed dimaknai sebagai nilai kemanusiaan dasar (universal), di antaranya adalah perlindungan hidup, hak milik, dan agama. Ketiga, nilai-nilai proteksional (Protectional Values). Nilai proteksional merupakan undang-undang bagi nilai fundamental yang berfungsi untuk memelihara keberlangsungan nilai fundamental. Keempat, nilai-nilai implementasional (Implementational $V$ alues). Nilai implementasional adalah langkah spesifik untuk melaksanakan nilai proteksional. Menurut Saeed, nilai implementasional yang terekam dalam alquran tidak bersifat universal. Kelima, nilai-nilai instruksional (Intructional Values). Nilai intruksional adalah ukuran atau tindakan yang diambil alquran ketika berhadapan dengan sebuah persoalan yang (berlaku) khusus pada masa pewahyuan.

Selanjutnya, dalam pendekatan kontekstual-nya, Abdullah Saeed menawarkan sebuah model pebacaan interaktif terhadap alquran. Dalam hal ini, pembaca adalah seseorang yang berpartisipasi aktif dalam memberikan makna terhadap teks, bukan sekadar seorang pasif yang hanya menerima makna teks. Dengan demikian, pembaca seharusnya melakukan proses interpretasi secara berkesinambungan (a continuous process) terhadap teks dan penulis sesuai dengan socio-historical context-nya (Zaini, 2011:32).

Ada empat langkah yang digunakan oleh Abdullah Saeed dalam melakukan kontekstualisasi, langkah pertama adalah pertimbangan awal yang memiliki tiga dimensi yaitu: dunia teks, pembaca, dan bahasa/makna. Langkah berikutnya adalah memulai tugas penafsiran dengan melihat akurasi dan reabilitas teks. Selanjutnya, dilakukan pula identifikasi makna teks dengan analisis makna linguistik sebagai dasar dari elemen-elemen teks, dan yang terakhir adalah mengaitkan penafsiran teks dengan konteks saat ini (Suryadilaga, 2015:331).

Dalam hal ini, langkah yang penulis lakukan ketika mengaplikasikan metode pendekatan kontekstual adalah menelaah teks, melacak makna kosa kata kunci, mencari konteks makro ketika masa Nabi saw. dalam rangka menemukan nilai universal teks itu, kemudian merujuk pada pendapat dan penafsiran ulama sebelumnya sebagai konteks penghubung (connector context) (Saeed, 2016:15), dan terakhir dikontekstualisasikan dengan kondisi sekarang. Berikut penulis sertakan skema pengaplikasian untuk mempermudah penjelasan. Berikut ini gambaran ringkas model penafsiran kontekstualis yang dikonsepsikan oleh Abdullah Saeed. 
Nalar: Jurnal Peradaban dan Pemikiran Islam

Vol. 2, No. 2, Desember 2018

Tabel 1. Model Penafsiran Abdullah Saeed (2015: 296)

\begin{tabular}{c} 
Teks \\
Tahap I: Perjumpaan dengan dunia Teks. \\
Tahap II: Analisis Kritis \\
Linguistik \\
Konteks literal \\
Bentuk literal \\
Teks-teks yang berkaitan \\
Preseden \\
Tahap III: Makna Bagi Penerima Pertama \\
Konteks sosio-historis \\
Pandangan dunia \\
Hakikat pesan: hukum, teologis, etis \\
Pesan: kontekstual versus universal \\
Hubungan pesan dengan keseluruhan pesan alquran \\
Tahap IV: Makna untuk saat ini \\
Analisis konteks saat ini \\
Konteks saat ini versus konteks sosio-historis \\
Makna dari penerima pertama kepada saat ini \\
Pesan: kontekstual versus universal \\
Penerapan untuk saat ini \\
\hline
\end{tabular}

\section{Interpretasi Hadis-hadis Kontradiktif Perihal Relasi Sosial Muslim dan Non- Muslim}

Perihal relasi antara muslim dan non-muslim seringkali dibenturkan dengan nash-nash alquran oleh kelompok fundamentalis. Sebagai contoh, ormas HTI dalam situs resminya mengutip tafsir Ibn Katsir atas QS. 4: 144 yang menjelaskan bahwa ayat itu mengandung larangan atas kaum mukmin untuk bersahabat, berteman, saling memberi dan meminta nasihat, berkasih sayang serta menyebarkan rahasia orang mukmin kepada mereka. Dengan berdasar pada dalil itu, ormas HTI mengambil sikap tentang keharaman menjadikan orang kafir sebagai pemimpin (penguasa) (Hizb-Indonesia.info, 2016).

Sementara dalam kitab Shahih Bukhari, terdapat riwayat yang mengisahkan tentang peristiwa hijrahnya Nabi Muhammad saw. dari Makkah menuju Madinah (Yasrib). Namun, yang menjadikan hadis itu menarik, pada peristiwa tersebut Nabi saw. yang ditemani Abu Bakar ra., menjadikan seorang kafir sebagai pemimpin atau penunjuk jalannya (bädiyan, hädin berasal dari kata hada). Jika dihadapkan dengan pemahaman HTI sebagaimana telah disebutkan, implikasinya adalah apa yang dilakukan oleh Rasulullah saw. telah menyalahi ajaran Islam -terlepas pada saat itu QS. 3: 28, QS. 4: 144, maupun QS. 5: 51 belum diwahyukan. Hal ini tentu memunculkan sebuah problem akademik sebab terkesan adanya 
Nalar: Jurnal Peradaban dan Pemikiran Islam

Vol. 2, No. 2, Desember 2018

kontradiksi antara nash alquran dan hadis. Oleh sebab itu, perlu dilakukan pengkajian lebih mendalam atas hadis itu.

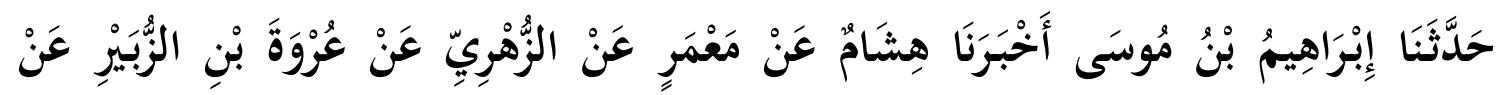

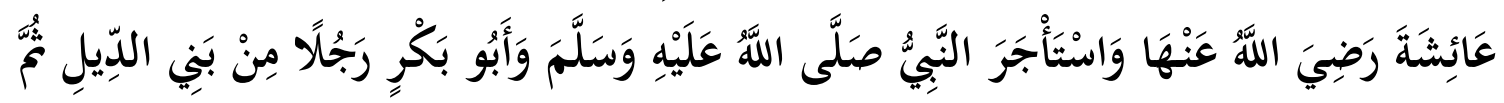

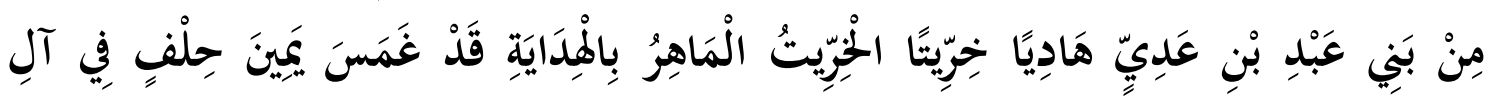

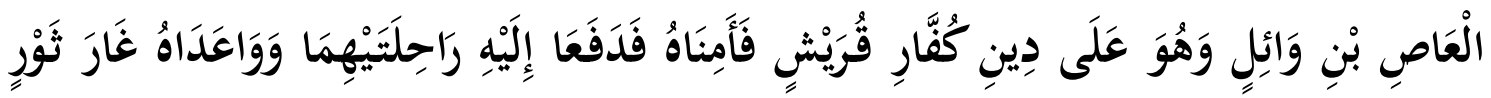

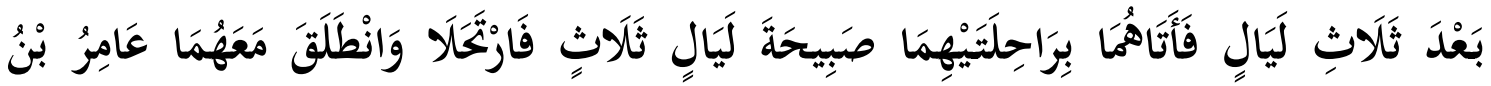

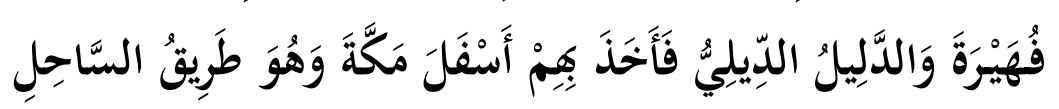

Artinya: "Nabi saw. dan Abu Bakar menyewa seseorang dari suku Ad-Dil keturunan dari suku 'Abdi bin 'Adiy sebagai penunjuk, jalan yang mabir dan menguasai seluk-beluk, perjalanan yang sebelumnya dia telah diambil sumpahnya pada keluarga $A l$ 'Ash bin Wa'il dan masib memeluk agama kafir Quraisy. Maka keduanya mempercayakan kepadanya perjalanan keduanya lalu keduanya meminta kepadanya untuk singgah di Gua Tsur setelah perjalanan tiga malam. Lalu orang itu meneruskan perjalanan keduanya waktu subuh malam ketiga, maka keduanya melanjutkan perjalanan dan berangkat pula bersama keduanya 'Amir bin Fuhairah dan penunjuk jalan suku Ad-Diliy tersebut. Maka penunjuk. jalan itu mengambil jalan dari belakang kota Makkah yaitu menyusuri jalan laut."

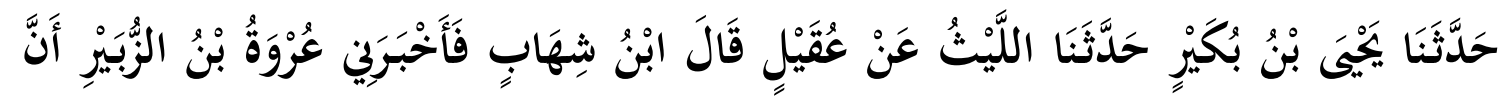

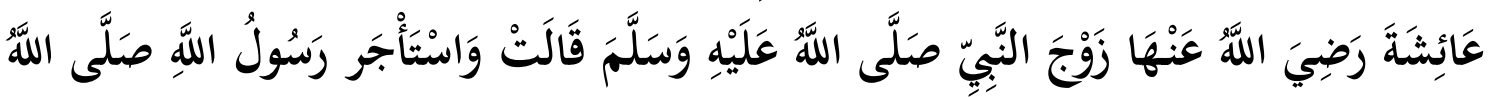

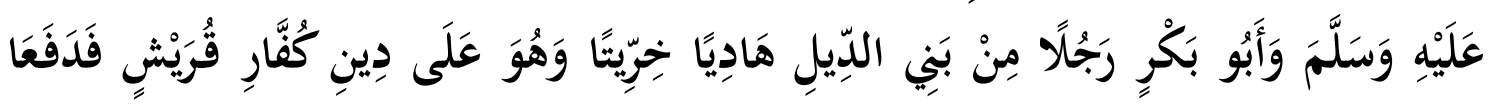

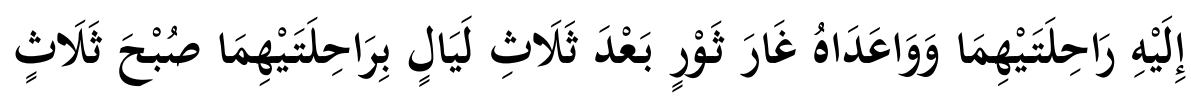

Artinya: "Rasulullah saw. dan Abu Bakar menyewa seseorang dari suku Ad-Dil sebagai penunjuk jalan yang dapat dipercaya yang mana keadaan orang itu masih memeluk agama kafir Quraisy. Maka keduanya mempercayakan kepadanya perjalanan keduanya lalu keduanya meminta kepadanya untuk. singgah di Gua Tsur setelah perjalanan tiga malam."

Sejauh penelusuran penulis, di antara kitab hadis kanonik (kutub sittab), hadis itu hanya terdapat dalam kitab Shahih Bukhori dengan tiga variasi teks. Masing-masing, dua di antaranya terdapat dalam pembahasan sewa-menyewa (jjärät, 2103-2104), dan satu yang terakhir pada pembahasan hijrah (bijratu an-nabi wa așhäbibi ila al-madinah, 3616). Sementara dalam kitab-kitab lainnya, hadis ini terdapat dalam kitab Bidāyah wa an-Nihāyah, kitab Daläilu an-Nubuwah lil Baihaqi, serta kitab as-Sunan al-Kubrā lil baihaqi. Selain itu, hadis tersebut merupakan hadis gharib, sebab hanya diriwayatkan oleh satu orang pada tobaqoh pertama 
Nalar: Jurnal Peradaban dan Pemikiran Islam

Vol. 2, No. 2, Desember 2018

('Aisyah), kedua ('Urwah bin Zubair), dan ketiga (Muhammad bin Muslim/Ibn Syihab/AzZuhri).

Konteks hadis itu menceritakan perjalanan hijrah Rasulullah saw. yang ditemani Abu Bakar, ketika menyelamatkan diri dari kejaran kafir Quraisy, hijrah dari Makkah menuju Yasrib. Diriwayatkan bahwa untuk menghindari kejaran kafir Quraisy, Nabi Muhammad dan Abu Bakar bersembunyi di dalam Gua Tsur. Setelah tiga hari bersembunyi, dan mengetahui situasi sudah aman dan tenang, Rasulullah saw., Abu Bakar, dan Abdullah bin Uraiqit yang dijadikan sebagai penunjuk jalan -dari Bani Du’il yang ketika itu masih memeluk agama kaum kafir Quraisy -pergi meninggalkan Makkah menuju Yasrib. Diceritakan bahwa Abdullah bin Uraiqit membawa mereka dengan hati-hati ke arah selatan di bawahan Makkah, kemudian menuju Tihamah di dekat pantai Laut Merah. Mereka mengambil jalan yang paling jarang dilalui orang sebagai upaya agar terhindar dari kejaran kaum kafir Quraisy (Haekal, 2010:183-187).

Jika dilihat dengan seksama, hadis di atas menyiratkan pesan perihal bolehnya menjadikan non-muslim sebagai penolong. Hadis itu dapat menjadi dasar bahwa dalam kondisi tertentu adalah boleh untuk menjadikan seorang kafir atau non-muslim sebagai pemimpin atau penolong, dalam konteks hadis itu adalah pemimpin atau penunjuk jalan (bädiyan berasal dari kata hadà). Ibnu Hajar al-Asqalani dalam Fathu al-Bārì (Syarh dari Shahih Bukhari), menjelaskan bahwa yang dimaksud oleh kata hädiyan khirritan adalah memiliki kecakapan sebagai penunjuk jalan (mähirun bi al-bidāyab). Dalam kitab itu, Ibnu Hajar al-Asqalani juga menyebutkan bahwa dalam keadaan tertentu adalah boleh bagi seorang muslim meminta bantuan (menyewa) seorang non-muslim. Namun demikian, ada syarat yang terlebih dahulu harus dipenuhi, pertama, dalam keadaan mendesak (dlarürah), kedua, tidak ada lagi orang muslim (Al-Asqalani 2001:517-518). Penulis sendiri memahami poin kedua sebagai tidak adanya lagi orang muslim yang mampu (memiliki pengetahuan), sebab dalam konteks peristiwa hijrah tersebut, masih ada muslim lainnya. Namun, karena pemandu (Abdullah bin Uraiqit) tersebutlah yang mampu (orang yang mengerti tentang jalur perjalanan), maka Rasulullah saw. dan Abu Bakar ra. memercayainya, dan menjadikannya sebagai penunjuk jalan.

Selain hadis di atas, ada juga riwayat setema lainnya, yang menceritakan bahwa Nabi Muhammad pernah menerima bantuan dari Shafwan bin Umayyah pada peristiwa perang Hunain dan Tha'if. Sementara pada saat itu, Shafwan bin Umayyah masih memeluk agama kafir Quraisy (Lasyin, 2002:401-404). Dalam hal ini, keberadaan hadis itu secara otomatis menguatkan hadis sebelumnya terkait relasi Nabi Muhammad dan non-muslim, bahwa Nabi saw. tidak menolak pertolongan orang kafir (sebagai penolong). Persoalan muncul kemudian dikarenakan adanya riwayat lain yang sifatnya kontradiktif, menceritakan perihal penolakan Rasulullah atas tawaran pertolongan orang kafir (lan asta'ina bi musyrikin).

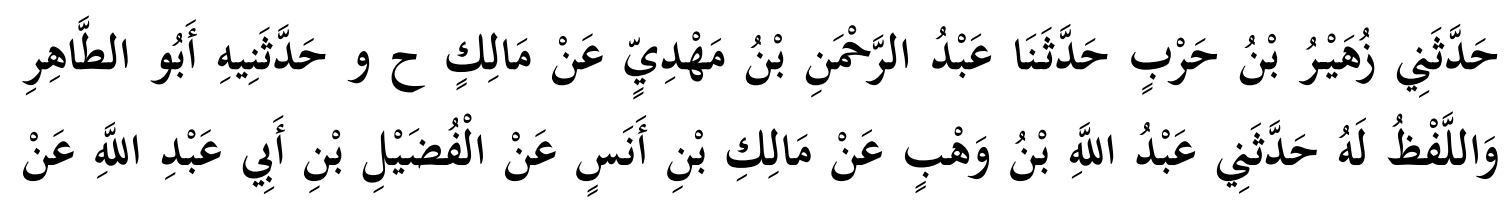




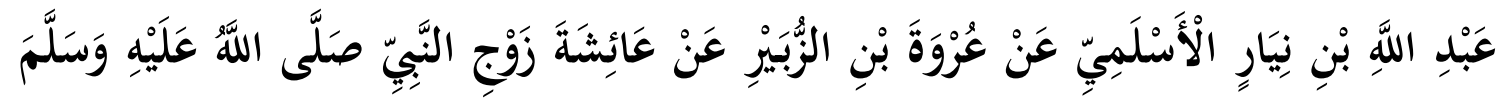

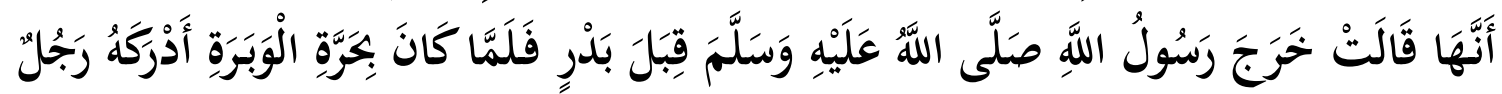

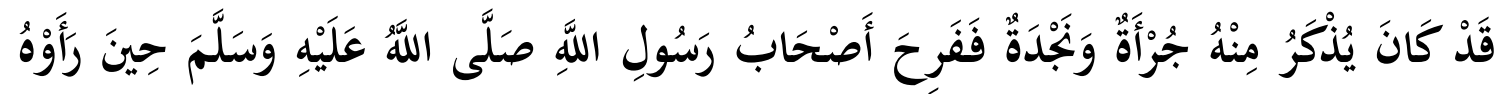

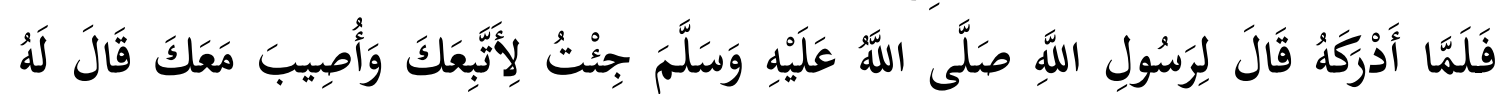

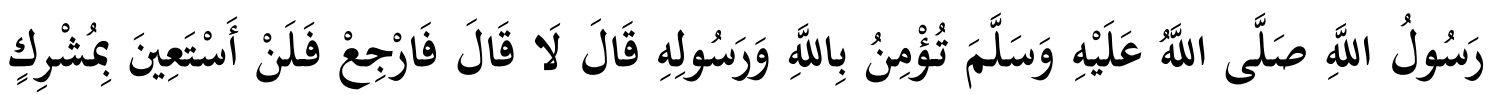

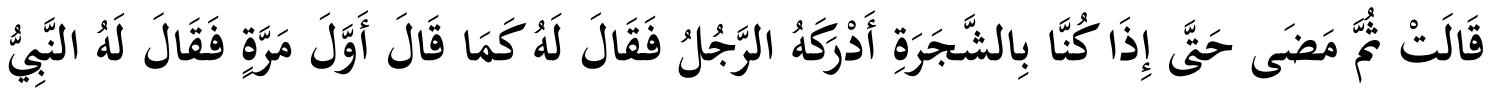

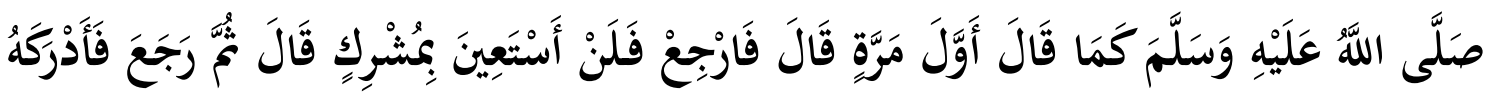

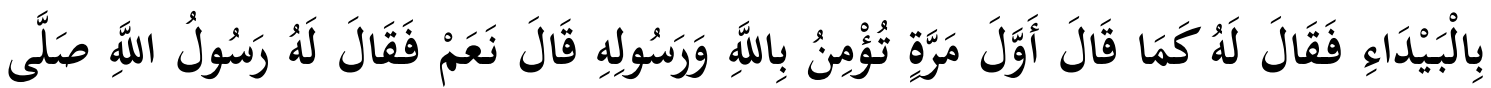

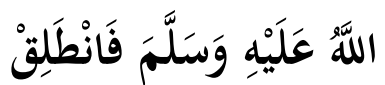

Artinya: Dari 'Aisyah isteri Nabi saw., bahwa dia berkata, "Rasulullah saw. pergi ke Badar, tatkala beliau sampai di Harratul Wabarah, beliau ditemui oleh seorang laki-laki yang terkenal gagah berani. Maka para sababat Rasulullah merasa gembira ketika melihat kedatangannya. Laki-laki tersebut berkata kepada Rasulullah, "Aku sengaja mengikuti anda karena bendak ikut berperang di pibak anda dan bersama-sama dengan anda." Rasulullah saw. bertanya kepadanya: "Apakah kamu sudah beriman kepada Allah Swt. dan Rasul-Nya?" dia menjawab, "Tidak." Beliau bersabda: "Iika demikian, kembalilah kamu pulang, sebab kami tidak membutubkan pertolongan orang-orang Musyrik." 'Aisyah berkata, "Maka pergilah orang itu, namun ketika kami dekat dengan sebatang pohon, orang itu datang kembali menemui Rasulullah saw. dan berkata seperti semula, sementara Nabi juga bertanya seperti semula. Selanjutnya beliau bersabda: "Tika demikian, kembalilah kamu pulang, sebab kami tidak membutubkan pertolongan orang-orang Musyrik." Dia berkata, "Maka pergilah dia, kemudian ketika kami sampai di baida', dia datang kembali, Rasulullab bertanya pula kepadanya seperti semula: "Apakah anda sudab beriman kepada Allah Swt. dan Rasul-Nya?" jawab orang itu, "Ya aku beriman." Maka Rasulullah bersabda kepadanya: "Mari, teruslah jalan."

Hadis ini menceritakan tentang penolakan Nabi saw. atas tawaran orang kafir yang hendak ikut membantu pasukan muslim pada peristiwa Perang Badar. Dalam redaksi hadis itu, secara tegas Rasulullah saw. menyampaikan penolakannya (lan asta'ina bi musyrikin). Hal ini tentu memunculkan ambiguitas, sebab pada riwayat lain Rasulullah menerima bantuan orang kafir, bahkan menjadikan orang kafir sebagai penunjuk jalannya (penolong) ketika hijrah ke Yasrib, sementara dalam hadis ini Rasulullah saw. secara tegas menolaknya. Selain itu, dibanding hadis-hadis yang telah dibahas sebelumnya, hadis ini lebih banyak diriwayatkan dalam kutub tis'ah dengan berbagai variasi redaksinya -terlepas bahwa hadis ini juga merupakan hadis gharib, sebab dari tobaqoh satu hingga lima, masing-masing diriwayatkan oleh satu orang. Di antaranya Shohih Muslim (3388), Sunan at-Tirmidzi 
Nalar: Jurnal Peradaban dan Pemikiran Islam

Vol. 2, No. 2, Desember 2018

(1479), Sunan Abu Dawun (2356), Sunan Ibnu Majah (2822), Musnad Ahmad (23250 dan 24003), Sunan ad-Darimi (2358).

Dalam hal ini, penulis mengutip penjelasan dalam Fathul Mun'im (pembahasan dilarangnya pertolongan orang kafir dalam peperangan), bahwa pesan moral hadis itu adalah kemaslahatan bagi umat muslim. Konteks hadis itu adalah peristiwa Perang Badar. Dalam kitab tersebut dijelaskan bahwa pertolongan dari selain sesama muslim (kafir) dalam peperangan melawan orang kafir adalah sangat berbahaya (khutürah syadidah), berbahaya bagi umat muslim, serta bahaya bagi Islam itu sendiri. Selain itu, kitab itu juga mengutip riwayat lain yang menjelaskan bahwa motif dari orang kafir untuk membantu muslim dalam peperangan adalah harta rampasan (sa aqtulu ma'aka min ajli al-mäl). Karenanya Nabi saw. menolak tawaran dari orang kafir itu dan berkata, "fa annà là asta'inu bi musyrikin." Oleh karena itu, hadis ini juga dijadikan dasar larangan bagi muslim menerima bantuan nonmuslim (dalam konteks perang). Berbeda halnya dalam konteks muamalah seperti jual-beli dan piutang, maka perihal itu diperbolehkan (Lasyin 2002:401-402).

Secara tekstual, teks-teks hadis di atas terlihat kontradiktif sehingga memunculkan ambiguitas. Di satu sisi, Rasulullah secara tegas menolak tawaran pertolongan orang kafir, tetapi di sisi lain Rasulullah juga pernah menerimanya, yakni ketika menerima bantuan Shafwan bin Umayyah pada peristiwa Perang Hunain, serta menerima pertolongan Abdullah bin Uraiqit pada saat hijrah meninggalkan Makkah menuju Yasrib. Oleh karena itu, penulis menggunakan metode interpretasi hadis Yusuf al-Qaradhawi, berupa pengkomromian (al-jam'u) hadis-hadis yang nampaknya bertentangan (mukhtalif) untuk memperoleh pemahaman.

Sebagaimana telah disebutkan, konteks hadis yang pertama bahwa Nabi saw. menjadikan Abdullah bin Uraiqit sebagai penunjuk jalan dikarenakan memiliki kecakapan sebagai penunjuk jalan (hädiyan khirritan) sehingga Rasulullah saw. dan Abu Bakar ra. memercayainya, dan menjadikannya sebagai penunjuk jalan. Sementara konteks hadis tentang penolakan Rasulullah atas tawaran pertolongan orang kafir pada peristiwa Perang Badar dikarenakan motif untuk membantu muslim adalah harta rampasan (sa aqtulu ma'aka min ajli al-māt), sehingga Nabi saw. menolak tawaran dari orang kafir.

Dengan melihat konteks masing-masing hadis, dapat dijumpai sebuah titik temu, bahwa dalam kondisi tertentu adalah diperbolehkan menjadikan orang kafir sebagai penolong bagi umat muslim. Adapun larangan untuk menjadikan orang kafir sebagai penolong tetap berlaku apabila hal itu justru berbahaya dan menjadikan mudarat bagi umat muslim dan Islam itu sendiri. Dalam hal ini, penulis juga mengutip pendapat Imam Syafi'i yang menyebutkan, bahwa apabila memang dibutuhkan adanya pertolongan dari orang kafir serta orang kafir itu memiliki cara pandang yang baik terhadap Islam (membawa maslahat), maka hal itu diperbolehkan (Lasyin 2002:404).

\section{Tinjauan atas Ayat Alquran tentang Larangan Menjadikan Non-Muslim sebagai Pemimpin}

Selain merujuk pada beberapa riwayat sebagaimana telah dibahas, penulis juga membandingkan hadis-hadis itu dengan ayat-ayat alquran yang memiliki tema serupa. Dalam hal ini, sejauh penelusuran penulis terdapat dua kelompok ayat yang secara eksplisit 
Nalar: Jurnal Peradaban dan Pemikiran Islam

Vol. 2, No. 2, Desember 2018

menyatakan larangan bagi seorang muslim untuk menjadikan non-muslim sebagai pemimpin -kata auliä's seringkali diterjemahkan sebagai pemimpin.

Kelompok pertama adalah ayat-ayat yang menggunakan redaksi kata kä́firin (berasal dari akar kata kafara). Di antara ayat-ayat yang menggunakan redaksi käfirin adalah QS. 3: 28 dan QS. 4: 144. Ayat-ayat itu, secara tekstual, berisi larangan bagi muslim untuk menjadikan orang kafir sebagai auliä, serta mengandung ancaman bagi orang-orang beriman apabila menjadikan orang kafir sebagai auliā' (là tattakhižù al-käfirina auliā). Sementara kelompok kedua adalah ayat yang menggunakan redaksi kata al-yabüd dan al-nașāra, yaitu QS. 5: 51. Pada ayat ini pun berisi larangan bagi muslim agar tidak menjadikan Yahudi dan Nasrani sebagai aulià' (là tattakhì̄ù al-yahüda wa al-nașārāa). Sementara ayat lain yang senada adalah QS. 8: 73. Namun demikian, ayat ini tidak secara eksplisit menggunakan redaksi larangan (la nahi). Ayat itu hanya menyebutkan bahwa orang-orang kafir menjadi pelindung bagi kafir yang lain.

Keseluruhan ayat di atas merupakan kelompok ayat madaniyah. Manna' Khalil alQattan menjelaskan bahwa ayat-ayat madaniyah memiliki ciri khusus yakni lebih banyak menjelaskan seputar ibadah, muamalah, kekeluargaan, warisan, jihad, relasi sosial, hubungan internasional, serta kaidah hukum dan perundang-undangan (Al-Qattan 2007:87). Ini sesuai dengan konten ayat-ayat sebagaimana telah disebutkan di atas.

\section{Konteks Penghubung: Penafsiaran Terdahulu atas QS. 3: 28 dan QS. 5: 51}

Alquran surah Ali Imran (3:28) secara eksplisit menyebutkan larangan kepada orang mukmin untuk tidak menjadikan orang-orang kafir sebagai wali-nya (auliä). Kata auliä adalah bentuk jamak dari kata wali yang dapat berarti teman akrab, dapat juga berarti pemimpin, pelindung, atau penolong. Berikut ayat dan terjemah lengkapnya:

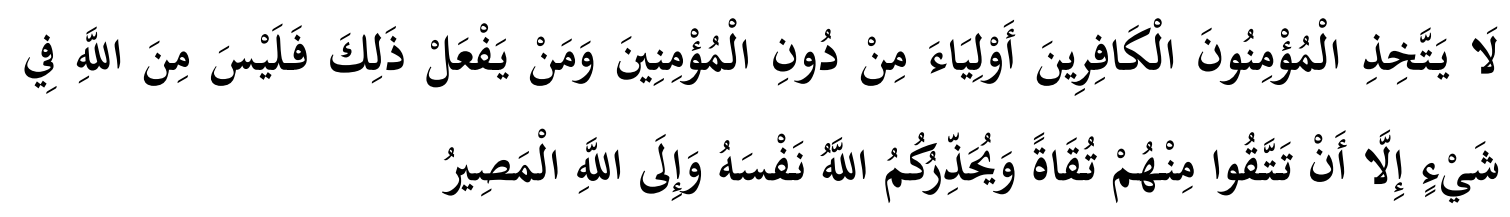

"Janganlah orang-orang mukmin mengambil orang-orang kafir menjadi wali dengan meninggalkan orangorang mukmin. Barang siapa berbuat demikian, niscaya lepaslah ia dari pertolongan Allah, kecuali karena (siasat) memelihara diri dari sesuatu yang ditakuti dari mereka. Dan Allah memperingatkan kamu terbadap diri (siksa)-Nya. Dan hanya kepada Allab kembali(mu)."

Menurut riwayat dari Ibnu Jarir at-Thobari dari Ibn 'Abbas, konteks diturunkannya QS. 3: 28 adalah ketika Al-Hajjaj bin Amr, Ka'ab bin al-Asyraf, Ibnu Abil Haqiq dan Qais bin Zaid (golongan Yahudi) tinggal dan berbaur bersama orang-orang Anshar dalam rangka untuk mengganggu ke-Islam-an mereka dan membujuk mereka untuk keluar dari Islam.

Maka Rifa'ah ibnul Mundzir, Abdullah bin Zubair, dan Sa'id bin Hatsamah berkata kepada mereka: "Jauhilah orang Yahudi itu dan janganlah tinggal bersama mereka agar mereka tidak membuat kalian keluar dari agama kalian." Kemudian turunlah ayat ini (AzZuhaili 2009 [juz 3]:215). 
Nalar: Jurnal Peradaban dan Pemikiran Islam

Vol. 2, No. 2, Desember 2018

Ayat ini diturunkan kepada sekelompok muslim pada waktu itu untuk waspada ketika berelasi dengan orang-orang Yahudi atau kafir, ini dikarenakan pada saat itu mereka sangat memusuhi Islam. Sehingga dikhawatirkan apabila bergaul dengan mereka akan menjadikan orang-orang muslim murtad.

Riwayat lain yang berasal dari Ibn 'Abbas menyebutkan bahwa ayat ini turun berkenaan dengan seorang sahabat yang bernama 'Ubadah bin Samit al-Anshari. Dia adalah seorang sahabat yang ikut serta berjuang dalam Perang Badar dan dia juga termasuk salah satu sahabat yang takwa. Ketika Nabi dan para sahabat hendak berangkat menuju Perang Badar, tiba-tiba 'Ubadah berkata pada beliau, "wahai Rasul, ada lima puluh laki-laki Yahudi bersama saya saat ini, mereka bersedia untuk membantu kita dalam peperangan dan bisa menambah jumlah pasukan kita sehingga menjadikan musuh kita takut.” Kemudian turunlah ayat ini (Al-Qurthubi 2008 [jilid 4]:156).

Ibnu Katsir dalam kitab tafsirnya menjelaskan, bahwa Allah Swt melarang kepada hamba-hambanya yang beriman untuk menjadikan orang-orang kafir sebagai wali mereka. Ibnu Katsir juga mencantumkan munasabah ayat di antaranya adalah QS. 4: 144, QS. 5: 51, QS. 60: 1, QS. 8: 73. Ibnu Katsir menambahkan, bahwa terdapat pengecualian bagi mereka yang takut akan perbuatan jahat orang kafir sebab sedang berada di daerah atau negara orang kafir (Katsir 2000:360).

Sementara Wahbah az-Zuhaili menafsirkan QS. 3: 28 bahwa Allah Swt. melarang orang-orang mukmin untuk memihak orang-orang kafir dalam urusan keluarga, persahabatan, tetangga, dan sebagainya, karena alasan persahabatan. Akan tetapi, apabila persahabatan dengan kaum kafir mengandung kemaslahatan, maka hal itu diperbolehkan. Nabi sendiri dikisahkan pernah bersekutu dengan Bani Khuza'ah, padahal mereka tetap dalam kemusyrikannya (Az-Zuhaili 2009 [juz 3]:216).

Sementara alquran surah al-Maidah (5: 51) secara tegas menyebutkan larangan bagi orang mukmin untuk menjadikan orang-orang Yahudi dan Nasrani sebagai wali-nya.

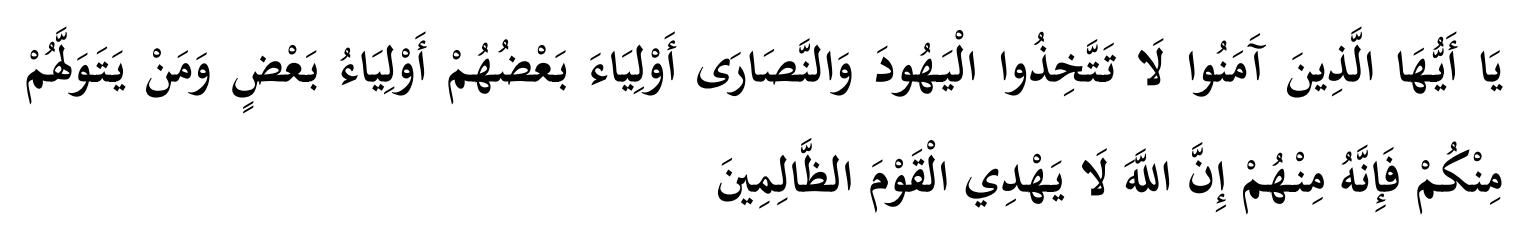

"Hai orang-orang yang beriman, janganlah kamu mengambil orang-orang Yabudi dan Nasrani menjadi pemimpin-pemimpin(mu); sebagian mereka adalah pemimpin bagi sebagian yang lain. Barang siapa di antara kamu mengambil mereka menjadi pemimpin, maka sesunggubnya orang itu termasuk golongan mereka. Sesunggubnya Allah Swt tidak memberi petunjuk kepada orang-orang yang ralim."

Konteks historis turunnya QS. 5: 51, diriwayatkan bahwa 'Ubadah bin As-Shamit seorang dari Bani Khazraj, datang kepada Rasulullah kemudian berkata, "Ya Rasulullah, sesungguhnya saya mempunyai sekutu-sekutu dari orang-orang Yahudi yang banyak jumlahnya. Dan sesungguhnya saya melepaskan diri demi Allah dan rasul-Nya dari persekutuan saya dengan orang-orang Yahudi, dan saya mengambil Allah dan Rasul-Nya menjadi penolongku." 
Nalar: Jurnal Peradaban dan Pemikiran Islam

Vol. 2, No. 2, Desember 2018

Maka, berkatalah Abdullah bin Ubay, "Sesungguhnya saya ini laki-laki yang khawatir akan terjadinya bencana-bencana. Maka saya takkan melepaskan diri dari persekutuan saya dengan sekutu-sekutuku."

Maka berkatalah Rasulullah Saw kepada Abdullah bin Ubay, "Ya Aba al-Habbab, bagaimana pendapatmu kalau persekutuan dengan orang-orang Yahudi yang kamu sayang melepaskannya demi ibadah itu ternyata membuahkan akibat sebaliknya?”

"Kalau begitu, baiklah saya terima", jawab Ibnu Ubay, yang kemudian Allah menurunkan wahyu-Nya QS. 5: 51 (At-Thabari 2001 [juz 8]:504).

Wahbah az-Zuhaili dalam tafsirnya menjelaskan bahwa kaum mukmin dilarang untuk menjadikan orang-orang Yahudi maupun Nasrani sebagai wali-nya yang memusuhi orangorang mukmin. Sesungguhnya orang-orang Yahudi menjadi penolong bagi sebagian mereka yang lain, begitu juga dengan orang-orang Nasrani (Az-Zuhaili, 2009 [juz 6]:578).

Sebagaimana telah disinggung di atas, bahwa kedua ayat ini merupakan kelompok madaniyah atau diwahyukan setelah peristiwa hijrahnya Nabi dan kaum muslim ke Madinah. Selain itu, kedua sabāb nuгūl ayat di atas jelas menunjukkan pola relasi yang terjalin antara kaum muslim dan Yahudi. Dalam hal ini yang perlu menjadi catatan adalah setelah hijrah ke Madinah, Nabi saw. di sana tinggal bersama orang-orang kafir yang dapat dikelompokkan dalam tiga golongan.

Terhadap masing-masing golongan itu, Nabi saw. telah memperlakukan sesuai dengan yang diperintah Allah Swt. Maka, diajaknya orang-orang Yahudi di Madinah untuk mengadakan perjanjian damai, lalu ditulisnya sebuah surat perjanjian keamanan antara Nabi saw. dengan mereka. Di waktu itu, kaum Yahudi yang ada di sekitar Madinah ada tiga golongan, yaitu: Bani Qainuqa', Bani Nadhir, dan Bani Quraizhah.

Namun sesudah Perang Badar, Nabi Saw diserbu oleh Bani Qainuqa', dan tampaklah dari mereka pengkhianatan dan dengki. Enam bulan sesudah itu, Bani Nadhir melanggar janji. Kemudian Bani Nadhir (dalam tarikh disebut Bani Quraizhah) melakukan pelanggaran yang sama ketika Nabi saw. ke luar menuju Perang khandaq. Bani Nadhir (dalam tarikh disebut Bani Quraizhah) inilah kaum Yahudi yang paling gigih memusuhi Nabi saw. (AlMaraghi 1992 [jilid 6]: 240-241).

Apabila diamati secara mendetail, QS. 3: 28 dan QS. 5: 51 adalah berbicara tentang "persekutuan" antara muslim dan non-muslim (termasuk di dalamnya kafir Quraisy, Yahudi, dan Nasrani). Dalam Tafsir al-Munir (Az-Zuhaili 2009 [juz 3]: 214/[juz 6]: 576) maupun Tafsir al-Maraghi (Al-Maraghi, 1946 [juz 3]: 131/[juz 6]: 134), kata auliä' pun diartikan sebagai penolong (nașìr, nușarā), penyokong (mu'in), teman setia atau sekutu (bulafä). Dalam konteks saat itu, larangan bagi muslim untuk menjadikan non-muslim sebagai wali sebab hal tersebut berbahaya bagi umat muslim (dararun lil muslimin) (AlMaraghi, 1946 [juz 3]:189).

\section{Term Käfir, al-Yahud, dan al-Nashara dalam alquran}

\section{Käfir}

Secara literal, kata kēfir berasal dari akar kata kafara (kaf, fa', dan ra') yang memiliki arti menutupi. Dalam kamus Al-Mawrid: A Modern Arabic-English Dictionary, kata käjir yang berasal dari kata dasar kafara memiliki arti yang sama dengan kata 
Nalar: Jurnal Peradaban dan Pemikiran Islam

Vol. 2, No. 2, Desember 2018

satara yang artinya menutupi atau menyembunyikan (to cover, hide) (Baalbaki 1995:897). Dari pengertian ini muncul beberapa ungkapan yang pada dasarnya dapat dikembalikan padanya, semisal malam disebut käfir, karena ia menutupi siang, petani disebut käfir karena pekerjaannya menutupi benih dengan tanah, bahkan tempat yang jauh dan terisolir dari keramaian juga disebut käfir karena keterisolirannya menjadikan tempat itu tertutup dari dunia luar (Galib 1998:62).

Term kufur dalam pelbagai bentuk kata jadinya ditemukan sebanyak 525 kali dalam alquran. Secara umum, pengertian kufr yang tercantum dalam alquran dapat dikembalikan pengertiannya sebagaimana pembahasan kebahasaan di atas, semisal: kuffär (bentuk jamak taksir dari käfir), terdapat dalam QS. 57: 20 yang berarti petani. Kaffara, yukaffiru, berarti menutupi, menghapuskan atau menghilangkan. Kata itu di dalam alquran terulang sebanyak 14 kali, dan kesemuanya berkaitan dengan penghapusan dosa. Kaffarah, berarti denda sebagai penebus kesalahan dapat ditemukan pada QS. 5: 45, 89, dan 95 (Galib 1998:62-63).

Penjelasan tersebut menunjukkan bahwa kufr dalam alquran tidak selalu menunjuk pada pengingkaran terhadap Tuhan dan Rasul-Nya. Kufr tidak selamanya datang dari orang ateis, musyrik, dan atau non-muslim lainnya. Orang-orang yang mengaku muslim pun, bisa saja terjerumus ke dalam perilaku kufr dalam pengertian tertentu. Semisal QS. 14: 7 yang mana kafartum ditujukan kepada orang-orang yang mengingkari atau menutup-nutupi nikmat Allah Swt (kufr nikmat).

\section{Al-Yahūd}

Kata al-yahüd dalam alquran diungkapkan sebanyak 9 kali, semuanya diungkapkan dengan nada kecaman kepada mereka. Sejumlah perilaku buruk yang melekat dalam diri mereka yang dirujuk dengan term al-yahüd, antara lain kecaman keras karena tidak hanya sering berprasangka buruk terhadap sesama manusia, bahkan juga berani berprasangka buruk kepada Allah Swt. dengan mengatakan bahwa tangan Allah Swt. terbelenggu (kikir), seperti disebut dalam QS. 5: 64. Alquran juga menyatakan bahwa orang-orang Yahudi tidak akan pernah merasa senang sebelum umat muslim mengikuti cara hidup mereka, sebagaimana disebut dalam QS. 2: 120 (Galib 1998:56).

\section{Al-Nașara}

Kata al-nașāà merupakan bentuk jamak dari kata nașrāni. Kata itu berasal dari akar kata nașara (nun, shad, ra) yang secara literal berarti menolong. Term al-nașārā dalam alquran menunjuk kepada pemeluk agama Nasrani (Kristen), yakni agama yang diturunkan Allah Swt kepada Bani Isra’il melalui Nabi Isa. Kata al-naṣārā di dalam alquran disebutkan sebanyak 15 kali, dan seperti halnya al-yahūd, term al-nașārā juga lebih banyak dikemukakan alquran dengan nada kecaman. Semisal terdapat pada QS. 5: 13, yakni kecaman alquran terhadap mereka karena sikap dan perilaku mereka yang mengubah kitab sucinya. Dalam QS. 5: 73, alquran juga mengecam mereka karena telah merubah aqidah tauhid, menjadi konsep trinitas. Sementara dalam QS. 9: 3, alquran mengecam mereka karena pengkultusan mereka terhadap Nabi Isa dan 
Nalar: Jurnal Peradaban dan Pemikiran Islam

Vol. 2, No. 2, Desember 2018

kemudian mengangkatnya sebagai anak Allah Swt, yang kemudian dimanifestasikan sebagai salah satu dari unsur Tuhan (QS. 5: 72) yang lebih dikenal dengan konsep trinitas (Galib 1998:57-59).

Kelindannya dengan QS. 5: 51, Yahudi dan Nasrani di dalam alquran juga diidentifikasi sebagai orang-orang kafir sebagaimana halnya orang-orang musyrik (QS. 98 : 1). Mereka diidentifikasi oleh alquran melalaui kata al-ladrina kafaru sebab pengingkaran atau penolakannya atas kerasulan Muhammad saw. Alquran secara tegas menyamakan kekafiran Yahudi dan Nasrani (abl kitab) dengan kekafiran orang-orang musyrik, yaitu sama-sama menentang dan menolak ajaran yang dibawa Nabi Muhammad saw. (Galib 1998: 65).

Meski demikian, perlu ditegaskan bahwa alquran tidak memukul rata terhadap mereka dalam kategori negatif. alquran juga mengindikasikan bahwa di antara mereka juga terdapat kelompok yang tetap memegang teguh ajaran agamanya, meski jumlahnya lebih kecil daripada yang telah menyimpang. Hal ini disebutkan dalam QS. 2: 62, QS. 5: 69, QS. 22: 17, yang mengindikasikan, bahwa bagi mereka yang tetap memegang teguh ajaran agamanya akan mendapatkan ganjaran dan keselamatan di akhirat sebagaimana halnya orang-orang yang beriman kepada Nabi Muhammad saw. (Galib 1998:60).

\section{Penafsiran Kontekstualis Perihal Kepemimpinan Non-Muslim Perspektif Alquran dan Hadis dalam Konteks Indonesia}

Kaitannya dengan pemilihan seorang wali (dalam arti pemimpin) dari kalangan nonmuslim, apabila QS. 3: 28 dan QS. 5: 51 dipahami secara tekstual tanpa melihat konteks historis ayat, maka dapat diambil simpulan bahwa menjadikan non-muslim sebagai pemimpin atau penolong adalah tidak dibenarkan, seperti halnya yang dipahami oleh ormas HTI maupun kelompok tekstualis-fundamentalis lainnya. Ini dapat menjadi polemik khususnya dalam konteks Indonesia, sebab masing-masing warga Indonesia (yang beragam suku, budaya, dan agamanya) memiliki hak yang sama untuk menjadi pemimpin. Jika pemahaman kalangan tekstualis-fundamentalis yang dipakai, maka seperti halnya firman Allah Swt. pada QS. 3: 28, sebagian besar umat muslim di Indonesia yang wilayahnya dipimpin oleh pemimpin non-muslim telah lepas dari pertolongan Allah Swt.: "Barang siapa berbuat demikian, niscaya lepaslah ia dari pertolongan Allah, kecuali karena (siasat) memelihara diri dari sesuatu yang ditakuti dari mereka," sementara umat muslim di Indonesia sama sekali tidak dalam keadaan tertekan ataupun dalam keadaan takut, oleh karenanya tidak ada perkecualian.

Indonesia adalah negara yang menganut paham demokrasi, yakni suatu sistem atau bentuk pemerintahan yang melibatkan segenap rakyat turut serta memerintah dengan perantaraan wakil-wakilnya. Paham demokrasi juga mengutamakan persamaan hak dan kewajiban serta perlakuan yg sama bagi semua warga negara. Karena itu, setiap warga negara Indonesia memiliki hak yang sama untuk menjadi pemimpin, tanpa melihat suku maupun agamanya. Untuk itu perlu dilakukan penafsiran kontekstualis untuk memahami QS. 3: 28 dan QS. 5: 51. Sebab, apabila cara pandang tekstualis yang digunakan tanpa melihat konteks sosio-historis, berpotensi melahirkan konflik sosial. 
Nalar: Jurnal Peradaban dan Pemikiran Islam

Vol. 2, No. 2, Desember 2018

Untuk itu, yang harus dilakukan adalah melihat konteks historis ayat dan nilai-nilai universal (konteks makro), serta kriteria seorang pemimpin sesuai yang diajarkan Islam. Dari konteks sabāb nu₹ul-nya, kedua ayat di atas melarang umat muslim bersekutu dengan non-muslim (Yahudi, Nasrani, Kafir). Ini bukan tanpa sebab, sebagaimana telah dijelaskan oleh al-Maraghi bahwa tiga golongan Yahudi yang turut serta dalam perjanjian Piagam Madinah, kesemuanya menghianati perjanjian itu. Bahkan dalam sejarah Islam disebutkan bahwa golongan Yahudi dari Bani Nadhir bersekutu dengan kaum kafir Makkah dalam Perang Handaq melawan umat muslim (Hakim 2003:34). Maka, adalah lumrah ketika alquran dalam banyak kesempatan memperingatkan umat muslim. Sementara terhadap Nasrani, kecaman alquran terhadap mereka karena perbuatannya yang telah melupakan janji mereka kepada Allah Swt. (QS. 5: 14). Mereka juga telah dengan sengaja merubah akidah tauhid yang diajarkan oleh Nabi Isa as., menjadi konsep trinitas (QS. 5: 73).

M. Quraish Shihab berpendapat bahwa antara al-yahūd dan al-nașārā memiliki bobot yang berbeda. Menurutnya, apabila alquran menggunakan kata al-yabūd, maka bisa dipastikan ayat itu berupa kecaman atas sikap-sikap buruk mereka. Sementara ketika menggunakan kata al-nașārā, maka hal itu belum tentu bersikap kecaman (Shihab 2006:348349). Dalam konteks hubungan sosial, kaum Nasrani memang cenderung lebih bersahabat dengan umat muslim. Hal ini dapat dilihat, antara lain dari sikap yang ditunjukkan oleh penguasa Habasyah (Ethiopia) yang menerima dan memberi perlindungan kepada umat muslim ketika hijrah ke daerahnya untuk menghindari penganiayaan kaum kafir Makkah. Namun demikian, alquran tetap memperingatkan umat muslim agar tetap waspada, sebab orang-orang Nasrani -sebagaimana halnya orang-orang Yahudi -tidak akan pernah merasa senang sebelum orang-orang muslim mengikuti cara hidup mereka (QS. 2: 120).

Berdasarkan uraian di atas, dapat dilihat bahwa titik tekan peringatan dalam QS. 3: 28 dan QS. 5: 51 terhadap umat muslim adalah pada sifat atau tabiat buruk dari kaum Yahudi dan Nasrani (konteks makro ayat). Alquran sendiri juga mengindikasikan bahwa di antara mereka terdapat kelompok yang tetap memegang teguh ajaran agamanya, meski jumlahnya lebih kecil daripada yang telah menyimpang seperti disebutkan dalam QS. 2: 62, QS. 5: 69, QS. 22: 17.

Mengutip Sahiron Syamsuddin (2017) atas penafsirannya terhadap QS. 5: 51, bahwa ide moral atau pesan utama dari ayat itu adalah, paling tidak, pertama, perintah untuk berteman dengan orang-orang yang bisa dipercaya, khususnya dalam hal-hal yang sangat penting dalam kehidupan bermasyarakat, dan larangan untuk memilih aliansi dan teman yang suka berkhianat. Prilaku adil kepada semua orang harus ditegakkan dan kezaliman/ketidakadilan harus ditinggalkan. Kedua, komitmen bersama dan saling menjaga perjanjian/kesepakatan bersama itu harus ditegakkan dan tidak boleh dikhiyanati. Apabila komitmen dan perjanjian itu dirusak secara sepihak, maka yang akan terjadi adalah kehilangan trust (kepercayaan) dari kelompok yang dikhiyanati, sebagaimana kehilangan trust umat muslim Madinah pada masa Nabi kepada kaum Yahudi dan Nasrani yang menyalahi The Medinan Charter (Piagam Madinah) yang salah satu intinya adalah saling menolong dan membantu antarkomunitas saat itu di Madinah. Ketiga, ayat itu tidak ada hubungannya dengan pemilihan kepala negara atau kepala daerah. Islam hanya mengajarkan bahwa kepala negara atau daerah sebaiknya orang yang mampu berbuat adil kepada seluruh 
Nalar: Jurnal Peradaban dan Pemikiran Islam

Vol. 2, No. 2, Desember 2018

masyarakat yang berada di wilayah kekuasaannya, tanpa memandang perbedaan agama dan suku.

Sementara itu, dalam memilih pemimpin hendaknya seseorang melihat nilai-nilai universal kriteria seorang pemimpin sesuai yang diajarkan Islam. Quraish Shihab menjelaskan bahwa di dalam alquran paling sedikitnya ditemukan dua sifat pokok yang harus dimiliki oleh seorang yang memikul suatu jabatan yang berkaitan dengan hak-hak masyarakat. Kedua hal tersebut dapat ditemukan dalam QS. 28: 26, yakni kuat (al-qawiy) dan dapat dipercaya (al-amin). Bahkan Allah Swt. memilih Jibril sebagai pembawa wahyunya, antara lain, karena Jibril memiliki sifat kuat lagi terpercaya (QS. 81: 19-21) (Shihab 2008:318-319). Dapat dibayangkan apabila seorang pemimpin suatu kaum, kota, maupun negara tidak memiliki dua sifat itu, maka dapat dipastikan kesejahteraan keadilan sosial tidak akan pernah terwujud. Seorang pemimpin yang tidak "kuat" dam tidak "terpercaya", maka ia akan dengan sangat mudah menyelewengkan kekuasaannya, baik itu berupa korupsi ataupun bentuk-bentuk penyelewengan lainnya.

Selanjutnya, seperti disebutkan QS. 3: 28, orang-orang mukmin hendaknya tidak memilih wali atau pemimpin dari kalangan orang kafir. Dalam hal ini, ada baiknya untuk kembali menengok pembahasan tentang kata käfir atau kufr. Seperti telah disebutkan bahwa kufr dalam alquran tidak selalu menunjuk pada pengingkaran terhadap Tuhan dan RasulNya. Kufr tidak selamanya datang dari orang ateis, musyrik, dan atau non-muslim lainnya. Orang-orang yang mengaku muslim pun, bisa saja terjerumus ke dalam perilaku kufr dalam pengertian tertentu. Semisal QS. 14: 7 yang mana kafartum ditujukan kepada orang-orang yang mengingkari atau menutup-nutupi nikmat Allah Swt. (kufr nikmat).

Kaitannya dengan riwayat tentang Rasulullah saw. yang menerima bantuan orang kafir (Abdullah bin Uraiqit dan Shofwan bin Umayyah), apabila konteks sosio-historis QS. 3: 28 dan QS. 5: 51 disandingkan dengan hadis itu, maka sama sekali tidak ada kontradiksi antara keduanya. Semisal, konteks sosio-historis QS. 5: 51, adalah berkaitan dengan penghianatan kaum Yahudi terhadap orang Islam, dan sama sekali tidak bersinggungan dengan pemilihan pemimpin dalam suatu wilayah. Tentang ini lebih lanjut juga dijelaskan dalam Tafsir al-Munir (Az-Zuhaili, 2009 [juz 5]:341) dan Tafsir al-Maraghi (Al-Maraghi 1946 [juz 5]: 189) bahwa mempekerjakan kafir drimmi dalam pemerintahan tidaklah dilarang (laisa bi mahzür), bahkan dikatakan bahwa Abu Ishaq as-Sabiy, seorang penganut șabiah (penyembah bintang) dijadikan sebagai wazir di masa kekhalifahan Abbasiyah.

Sebagaimana disebutkan dalam pembahasan hadis, bahkan Nabi Muhammad saw., dalam situasi tertentu, pernah "memercayakan urusannya" kepada orang kafir dengan menjadikannya sebagai penunjuk jalan ketika hendak hijrah ke Yasrib. Kaitannya dengan pemimpin, riwayat itu dapat dijadikan sebagai dasar argumentasi, bahwa dalam kondisi tertentu adalah boleh menjadikan seorang non-muslim sebagai pimpinan jika itu memang memberikan mașlahat. Apabila mengandung madorot, bahkan bergaul dengan sesama orang yang beragama Islam sekalipun, adalah wajib dihindari, sebagai contoh bergaul dengan orang yang beragama Islam tetapi menjadi pengedar narkoba, penjudi, dan semacamnya.

Di Indonesia, terlampau mudah untuk mendapatkan berita seorang pemimpin muslim yang melakukan penyelewengan atas kekuasaannya (korupsi). Sejarah mencatat, mulai dari pemimpin pada tingkat bawah (desa) hingga presiden, sebagian-(besar)-nya 
Nalar: Jurnal Peradaban dan Pemikiran Islam

Vol. 2, No. 2, Desember 2018

tersandung kasus korupsi. Sudah barang tentu hal tersebut menyalahi spirit suci alquran yang humanis dan menjunjung tinggi asas keadilan. Dalam konteks ini, bahkan seorang pemimpin yang notabene seorang muslim pun dapat digolongkan sebagai kafir, dalam arti menutup-nutupi kebenaran dan keadilan.

Oleh karena itu, memahami QS. 3: 28 dan QS. 5: 51, penulis mengamini pendapat Ibnu Taimiyah yang menyatakan "lebih baik dipimpin oleh pemimpin kafir (non-muslim) yang adil, daripada dipimpin oleh pemimpin muslim yang dzalim." Sebab, orang yang dapat diangkat menjadi pemimpin adalah orang yang memiliki kekuatan dan integritas, mampu berbuat adil dan memiliki komitmen yang kuat terhadap kemakmuran rakyat yang ia pimpin terlepas dari latar belakang keimanannya.

Hemat penulis, dalam konteks Indonesia, pertanyaan yang lebih tepat untuk dikemukakan adalah bukan boleh tidaknya menjadikan seorang non-muslim sebagai pemimpin, akan tetapi seberapa bobroknya moral calon-calon pemimpin dari kalangan muslim, sehingga banyak umat muslim yang tidak percaya bahkan putus asa, dan lebih percaya terhadap non-muslim menjadi pemimpin -terlepas dari asas demokrasi yang dianut oleh Indonesia. Dengan merujuk pada hadis serta ayat alquran sebagaimana telah dibahas serta konteks Indonesia yang heterogen, penulis berpendapat bahwa seorang calon pemimpin non-muslim yang memiliki kredibilitas, kuat, serta dapat dipercaya tentunya baik untuk dipilih. Namun, jika ada seorang calon pemimpin muslim, memiliki kredibilitas, kuat, dan dapat dipercaya, maka itu lebih utama untuk dijadikan pemimpin.

\section{Penutup}

Terkait wacana kepemimpinan non-muslim, kelompok tekstual-fundamentalis cenderung fokus memberikan penekanan pada aspek boleh-tidaknya seorang muslim memilih non-muslim sebagai pemimpin. Kelompok tekstual-fundamentalis, yang direpresentasikan oleh ormas HTI misalnya, "tanpa sengaja" telah melewatkan hal yang esensi, yaitu kriteria seorang pemimpin. Untuk menjadi pemimpin, seseorang haruslah memiliki kredibilitas, kuat, serta dapat dipercaya, sehingga ia mampu menciptakan kesejahteraan dan keadilan sosial di masyarakat. Oleh sebab itu, perlu untuk melakukan penafsiran kontekstual terhadap QS. 3: 28, QS. 5: 51, serta hadis-hadis terkait, kemudian mengelaborasikannya dengan nilai-nilai universal (konteks makro) yang dicita-citakan oleh Islam.

Adapun konteks larangan yang termaktub dalam QS. 3: 28 dan QS. 5: 51, merupakan peringatan agar umat muslim berhati-hati terhadap sifat atau tabiat buruk kaum Yahudi dan Nasrani, dan bukannya larangan atau tidak bolehnya seorang muslim membangun relasi dengan non-muslim, termasuk di dalamnya memilih non-muslim sebagai pemimpin. Sementara konteks penolakan Rasulullah saw. atas tawaran pertolongan orang kafir pada peristiwa Perang Badar dikarenakan motif utama mereka adalah untuk mendapatkan harta rampasan. Namun, apabila memang dibutuhkan adanya pertolongan dari orang kafir serta orang kafir itu memiliki cara pandang yang baik terhadap Islam (membawa maslahat), maka hal itu diperbolehkan, sebagaimana dilakukan oleh Nabi Muhammad saw. ketika menerima pertolongan Abdullah bin Uraiqit dan Shofwan bin Umayyah. 
Nalar: Jurnal Peradaban dan Pemikiran Islam

Vol. 2, No. 2, Desember 2018

\section{Daftar Pustaka}

Al-Asqalani, Ahmad bin Ali bin Hajar. 1421 H/2001. Fathu al-Bärì (juz 4), Riyadh: Maktabah Malik Fahd.

Bay, Kaizal. 2011. "Metode Penyelesaian Hadis-hadis Mukhtalif Menurut al-Syafi'i” dalam Jurnal Ushuluddin, Vol. XVII No. 2, Riau: Universitas Islam Negeri Sultan Syarif Kasim.

Galib, Muhammad. 1998. Abl al-Kitab: Makna dan Cakupannya, Jakarta: Paramadina.

Hakim, Moh. Nur. 2003. Sejarah dan Peradaban Islam, Malang: UMM Press.

Husain Haekal, Muhammad. 2010. Sejarah Hidup Mubammad (terj. Ali Audah), Jakarta: Litera AntarNusa.

Katsir, Ibnu. 2000. Tafsir al-Qur'an al-Adhim, Beirut: Dar Ibnu Hazm.

Khalik, Abu Tholib. 2014. "Pemimpin Non-Muslim dalam Perspektif Ibnu Taimiyah" dalam Analisis: Jurnal Studi Keislaman, Volume 14, Nomor 1, Lampung: Institut Agama Islam Negeri Raden Intan Lampung.

Lasyin, Musa Syahin. 1423 H/2002. Fathul Mun'im Syarb Shahih Muslim (juz 7), Kairo: Dar as-Syuruq.

Maraghi, Ahmad Musthafa. 1992. Tafsir Al-Maraghi (terj.) (jilid 6), Semarang: Karya Toha Putra.

Maraghi, Ahmad Musthafa. 1946. Tafsir Al-Maraghi (juz 3, juz 5, juz 6), Mesir: Mustafa alBabi al-Halabi.

Qaradlawi, Yusuf. 1992. Kaifa Nata'ämalu ma'a as-Sunnah an-Nabawiyyah, Virginia-Amerika: Dar al-Wafa.

Qattan, Manna' Khalil. 2007. Studi Ilmu-Ilmu al-Qur'an (terj.), Jakarta: Litera AntarNusa.

Qurthubi. 2008. Tafsir al-Qurthubi, terj. (jilid 4,) Dudi Rosyadi, Nashirul Haq dkk. Jalarta: Pustaka Azzam.

Rachmawan, Hatib. 2013. "Hermeneutika Al-Qur'an Kontekstual: Metode Menafsirkan AlQur'an Abdullah Saeed” dalam Afkaruna: Jurnal Ilmu-Imu Keislaman, Vol.9 No.2 JuliDesember 2013, Yogyakarta: Universitas Muhammadiyah Yogyakarta.

Rohi Baalbaki. 1995. Al-Mawrid: A Modern Arabic-English Dictionary (7th), Beirut: Dar al-Ilm li al-Malayin.

Saeed, Abdullah. 2015. Paradigma, Prinsip dan Metode Penafsiran Kontekstualis atas al-Qur'an (terj.), Yogyakarta: Ladang Kata kerja sama dengan Baitul Hikmah Press.

Saeed, Abdullah. 2016. Al-Qur'an Abad 21; Tafsir Kontekstualis (terj.), Bandung: Mizan.

Shihab, M. Quraish. 2008. Lentera al-Qur'an: Kisah dan Hikmah Kebidupan, Bandung: Mizan.

Shihab, M. Quraish. 2006. Wawasan al-Qur'an: Tafsir Maudhu'i atas Pelbagai Persoalan Umat, Bandung: Mizan.

Suryadilaga, Muhammad Alfatih. 2015. "Hadis dan Perannya dalam Tafsir Kontekstualis Perspektif Abdullah Saeed" dalam Mutawatir: Jurnal Keilmuan Tafsir Hadis, Volume 5, Nomor 2, Desember 2015, Surabaya: Universitas Islam Negeri Sunan Ampel.

Syamsuddin, Sahiron. 2009. Hermenentika dan Pengembangan Ulumul Qur'an, Yogyakarta: Nawesea Press.

Thabari, Ibn Jarir. 2001. Jami' al-Bayan an Ta'wil al-Qur'an, (juz 8) Kairo: Dar Hijr. 
Nalar: Jurnal Peradaban dan Pemikiran Islam

Vol. 2, No. 2, Desember 2018

Zaini, Achmad. 2011. "Model Interpretasi Al-Qur'an Abdullah Saeed" dalam Islamica, Vol. 6, No. 1, September 2011, Surabaya: Universitas Islam Negeri Sunan Ampel.

Zuhaili, Wahbah. 2009. Tafsir Al-Munir Fil Aqidah Wasy-Syari'ah Wal Manhaj, (juz 3, juz 5, juz 6) Damsyiq: Dar al-Fikr.

\section{Sumber Elektronik:}

Kompas.com, 2012. Panwaslu Rekonstruksi Ceramah SARA Rhoma Irama, diakses pada 24 November 2018 , source: https://megapolitan.kompas.com/read/2012/08/02/1455 3779/Panwaslu.Rekonstruksi.Ceramah.SARA.Rhoma.Irama.

Syamsuddin, Sahiron, 2017. Penafsiran Kontekstualis Atas Q.S. al-Ma’idah: 51, diakses pada 27 Mei 2018, source: http://uin-suka.ac.id/id/kolom/detail/20/penafsirankontekstualis-atas-qs-al-maidah-51

Hizb-Indonesia.info, 2016. Pemimpin Kafir Haram!, diakses pada diakses pada 22 Oktober 2018, http://hizb-indonesia.info/2016/08/10/pemimpin-kafir-haram/

Kompas.com, 2016. PBNU Merujuk ke Fatwa 1999 tentang Pemimpin Non-Muslim, diakses pada 07 Juni 2018, source: https://megapolitan.kompas.com/read/2016/09/15/ 16462071/pbnu.merujuk.ke.fatwa.1999.tentang.pemimpin.non-muslim.

Tribunnews.com, 2017. Kiai Muda NU: Argumen Umat Islam Tidak Melarang Pilih Pemimpin Non-Muslim, diakses pada 07 Juni 2018, source: http://www.tribunnews.com/ metropolitan/2017/03/14/kiai-muda-nu-argumen-umat-islam-tidak-melarangpilih-pemimpin-non-muslim

Tempo.co, 2017. Saksi Abli Tafsir UIN: Abok Kritik Politikus yang Pakai Al-Maidah, diakses pada 08 Juni 2018, source https://m.tempo.co/read/news/2017/03/30/ 063860762/saksi-ahli-tafsir-uin-ahok-kritik-politikus-yang-pakai-al-maidah

Republika.co.id, 2016. Puluban Ribu Massa Dukung Pemimpin Muslim, diakses pada 08 Juni 2018, source: https://www.republika.co.id/berita/nasional/jabodetabeknasional/ 16/09/04/ ocz5uy282-puluhan-ribu-massa-dukung-pemimpin-muslim 